\title{
WARALABA (FRANCHISE) DALAM SISTEM HUKUM ISLAM DAN HUKUM POSITIF DI INDONESIA
}

\author{
Riezka Eka Mayasari \\ Mahasiswa Program Doktor Ilmu Hukum Pascasarajana UMI Makassar \\ email : riezka eka mayasari@ymail.com
}

\begin{abstract}
Franchise (Franchise) is one type of modern business that provides a promising advantage. This franchise business also has the benefit that plays an important role in improving the development of small business. In terms of packaging The franchise of this franchise business is also a positive value that can be justified according to Islamic law. In Islamic law, franchise with this model is almost similar to the model syirkah mudharabah (profit sharing), but has progressed with the development of the era and there is a combination of other types of shirkah.
\end{abstract}

Keywords: Franchise (Franchise), Islamic Law.

\begin{abstract}
Abstrak
Waralaba (Franchise) adalah salah satu jenis bisnis modern yang memberikan keuntungan yang menjanjikan. Bisnis waralaba ini juga memiliki manfaat yang memainkan peran penting dalam meningkatkan pengembangan bisnis kecil. Dalam hal pengemasan Waralaba bisnis waralaba ini juga merupakan nilai positif yang dapat dibenarkan menurut hukum Islam. Dalam hukum Islam, waralaba dengan model ini hampir mirip dengan model syirkah mudharabah (bagi hasil), tetapi telah berkembang seiring perkembangan zaman dan ada kombinasi jenis syirkah lainnya.
\end{abstract}

Kata kunci: Waralaba; Hukum Islam.

\section{A. PENDAHULUAN}

Berbagai jenis bisnis baru telah muncul dan menyebar keseluruh penjuru dunia saat ini, termasuk Indonesia yang sebagai salah satu Negara yang perkembangan bisnisnya cukup pesat dikarenakan kebutuhan masyarakat yg semakin meningkat.Bisnis baru yang ditawarkan yaitu Waralaba (Franchise)yang menjanjikan keuntungan yang berlipat ganda.

Dalam istilah perdagangan dikenal dengan waralaba/franchising, transaksi bisnis yang bertaraf franchise. Keberhasilan dari suatu organisasi Waralaba tergantung dari penerapan Sistem/Metode Bisnis yang sama antaraPewaralaba dan Terwaralaba. Sistem bisnis tersebut berupa pedoman yang mencakup standarisasi produk, metode untuk mempersiapkan atau mengolah produk atau makanan, atau metode jasa, standar rupa dari fasilitas bisnis, standar periklanan, system reservasi, sistem akuntansi, kontrol persediaan, dan kebijakan dagang, dan lain sebagainya

Menurut Pasal 1 Keputusan Menteri Perindustrian dan Perdagangan RI No.

Vol. 20 No. 2 November 2018 
259/MPP/KEP/7/1997 tentang tata cara pelaksanaan pendaftaran waralaba, pengertian waralaba (franchisee) adalah: "perikatan di mana salah satu pihak diberikan hak untuk memanfaatkan dan/atau menggunakan hak atas kekayaan intelektual atau penemuan atau ciri khas usaha yang dimiliki pihak lain dengan suatu imbalan berdasarkan persyaratan yang ditetapkan pihak lain tersebut dalam rangka penyediaan dan/atau penjualan barang atau jasa". Pada dasarnya Franchisee adalah sebuah perjanjian mengenai metode pendistribusian barang dan jasa kepada konsumen.Franchisor dalam jangka waktu tertentu memberikan lisensi kepada franchisee untuk melakukan usaha pendistribusian barang atau jasa di bawah nama identitas franchisor dalam wilayah tertentu. Usaha tersebut harus dijalankan sesuai dengan prosedur dan cara yang ditetapkan oleh franchisor. Franchisor memberikan bantuan (assistance) terhadap franchise, sebagai imbalannya franchisee membayar jumlah uang berupa initial fee dan royalty.

Di samping itu, terdapat pula peraturan perundang-undangan yang mengatur tentang transaksi ekonomi era modern ini yang dikeluarkan oleh pemerintah sebagai upaya penertiban transaksi ekonomi yang ada dan berkemabang dimsyarakat Indonesia yang mayoritas memeluk agama Islam. Oleh karena mayoritas masyarakat di Indonesia beragama Islam, maka hukum positif (Ius Constitutum) yang mengatur hal tersebut harus pula dikaji kejelasannya menurut hukum Islam.

Dalam hukum Islam, waralaba dengan model ini hampir serupa dengan model syirkah mudharabah (bagi hasil), tapi sudah mengalami kemajuan seiring berkembangnya zaman dan terdapat gabungan dengan jenis syirkah lainnya.Syirkah (persekutuan) dalam hukum Islam banyak sekali jenisnya dan terdapat perbedaan oleh para imam madzhab.Dan perlu diketahui bahwa dalam pola transaksi yang diatur oleh hukum Islam adalah menitikberatkan pada sisi moralitas yang lebih tinggi dari pada apapun.

\section{B. ANALISIS DAN PEMBAHASAN}

\section{Bisnis Franchise dalam Perspektif Hukum Positif}

Di Indonesia, sistem waralaba mulai dikenal pada tahun 1950-an, yaitu dengan munculnya dealer kendaraan bermotor melalui pembelian lisensi. Perkembangan kedua dimulai pada tahun 1970-an, yaitu dengan dimulainya sistem pembelian lisensi plus, yaitu franchisee tidak sekedar menjadi penyalur, namun juga memiliki hak untuk memproduksi produknya .Agar waralaba dapat berkembang dengan pesat, maka persyaratan utama yang harus dimiliki satu teritori adalah kepastian hukum yang mengikat baik bagi franchisor maupun franchisee.Karenanya, kita dapat melihat bahwa di negara yang memiliki kepastian hukum yang jelas, waralaba berkembang pesat, misalnya di AS dan Jepang. Tonggak kepastian hukum akan format waralaba di Indonesia dimulai pada tanggal 18 Juni 1997, yaitu dengan dikeluarkannya Peraturan Pemerintah (PP) RI No. 16 Tahun 1997 tentang Waralaba. PP No. 16 tahun 1997 tentang waralaba ini telah dicabut dan diganti dengan PP no 42 tahun 2007 tentang Waralaba. Selanjutnya ketentuan-ketentuan lain yang mendukung kepastian hukum dalam format bisnis waralaba adalah sebagai berikut: 
- Keputusan Menteri Perindustrian dan Perdagangan RI No. 259/MPP/KEP/7/1997 Tanggal 30 Juli 1997 tentang Ketentuan Tata Cara Pelaksanaan Pendaftaran Usaha Waralaba.

- Peraturan Menteri Perindustrian dan Perdagangan RI No. 31/M-DAG/PER/8/2008 tentang Penyelenggaraan Waralaba

- Undang-undang No. 14 Tahun 2001 tentang Paten.

- Undang-undang No. 15 Tahun 2001 tentang Merek.

- Undang-undang No. 30 Tahun 2000 tentang Rahasia Dagang.

Menurut pasal 1 PP No. 16 Tahun 1997 tentang tata cara pelaksanaan pendaftaran waralaba, pengertian waralaba (franchisee) adalah : "perikatan di mana salah satu pihak diberikan hak untuk memanfaatkan dan/atau menggunakan hak atas kekayaan intelektual atau penemuan atau ciri khas usaha yang dimiliki pihak lain dengan suatu imbalan berdasarkan persyaratan yang ditetapkan pihak lain tersebut dalam rangka penyediaan dan/atau penjualan barang atau jasa".

Waralaba dapat dibedakan menjadi dua bentuk, yaitu waralaba merek dan produk dagang (product and trade franchise) dan waralaba format bisnis (business format franchise).Dalam Waralaba merek dagang dan produk, pemberi waralaba memberikan hak kepada penerima waralaba untuk menjual produk yang dikembangkan oleh pemberi waralaba disertai dengan izin untuk menggunakan merek dagangnya.Atas pemberian izin pengunaan merek dagang tersebut pemberi waralaba mendapatkan suatu bentuk bayaran royalty di muka, dan selajutnya dia juga mendapat keuntungan dari penjualan produknya. Misalnya: Mini Market menggunakan nama/merek dagang ALFA MART.

Sedangkan waralaba format bisnis adalah pemberian sebuah lisensi oleh seseorang kepada pihak lain, lisensi tersebut memberikan hak kepada penerima waralaba untuk berusaha dengan menggunakan merek dagang atau nama dagang pemberi waralaba dan untuk menggunakan keseluruhan paket, yang terdiri dari seluruh elemen yang diperlukan untuk membuat seseorang yang sebelumnya belum terlatih menjadi terampil dalam bisnis dan untuk menjalankannya dengan bantuan yang terus-menerus atas dasar-dasar yang telah ditentukan sebelumnya. Waralaba format bisnis ini terdiri dari :

- Konsep bisnis yang menyeluruh dari pemberi waralaba.

- Adanya proses permulaan dan pelatihan atas seluruh aspek pengelolaan bisnis, sesuai dengan konsep pemberi waralaba.

- Proses bantuan dan bimbingan terus-menerus dari pihak pemberi waralaba.

Dalam bisnis franchise ini, yang dapat diminta dari franchisor oleh franchisee adalah sebagai berikut :

- Brand name yang meliputi logo, peralatan dan lain-lain.Franchisor yang baik juga memiliki aturan mengenai tampilan / display perwakilan took (Shopfront) dengan baik dan detail.

- System dan manual operasional bisnis. Setiap Franchisor memiliki standar operasi yang sistematis, praktis serta mudah untuk diterapkan, dan mestinya juga tertuang dalam bentuk tertulis.

- Dukungan dalam beroperasi. Karena Franchisorlebih mempunyai pengalaman luas Vol. 20 No. 2 November 2018 
serta sudah membina banyak Franchisees, sudah sepatutnya memiliki kemampuan untuk memberikan dukungan bagi Franchisee yang baru.

- Pengawasan (monitoring). Untuk memastikan bahwa sistem yang disediakan dijalankan dengan baik dan benar secara konsisten.

- Penggabungan promosi/joint promotion, hal ini berkaitan dengan brand name.

- Pemasokan, ini berlaku bagi franchisee tertentu, misalnya bagi franchisor yang merupakan supplier bahan makanan/minuman. Kadang franchisor juga memasok mesin-mesin atau peralatan yang diperlukan.

Franchisor yang baik biasanya ikut membantu franchisee untuk mendapatkan sumber dana modal dari investor (fund supply) seperti bank misalnya, meskipun itu jarang sekali. Perjanjan waralaba adalah perjanjian formal.Hal tersebut dikarenakan perjanjian waralaba memang disyaratkan pada pasal 2 PP No. 16 Tahun 1997 untuk dibuat secara tertulis dalam bahasa Indonesia.Hal ini diperlukan sebagai perlindungan bagi kedua belah pihak yang terlibat dalam perjanjian waralaba.

Secara umum dikenal adanya dua macam atau jenis kompensasi yang dapat diminta oleh pemberi waralaba (franchisor) dari penerima waralaba (franchisee).Pertama, kompensasi langsung dalam bentuk moneter (direct monetary compensation) adalah lump sum payment dan royalty.Lump sum payment adalah suatu jumlah uang yang telah dihitung terlebih dahulu yang wajib dibayarkan oleh penerima waralaba (franchisee) pada saat persetujuan pemberian waralaba disepakati.Sedangkan royalty adalah jumlah pembayaran yang dikaitkan dengan suatu presentasi tertentu yang dihitung dari jumlah produksi dan/atau penjualan barang dan/atau jasa yang diproduksi atau dijual berdasarkan perjanjian, baik disertai dengan ikatan suatu jumlah minimum atau maksimum jumlah royalty tertentu atau tidak.

Kedua, kompensasi tidak langsung dalam bentuk nilai moneter (indirect and nonmenetary compensation). Meliputi antara lain keuntungan sebagai akibat dari penjualan barang modal atau bahan mentah, yang merupakan satu paket dengan pemberian waralaba, pembayaran dalam bentuk deviden ataupun bunga pinjaman dalam hal pemberi waralaba juga turut memberikan bantuan financial, baik dalam bentuk ekuitas atau dalam wujud pinjaman jangka pendek maupun jangka panjang, cost shifting atau pengalihan atas sebagian biaya yang harus dikeluarkan oleh pemberi waralaba, perolehan data pasar dari kegiatan usaha yang dilakukan oleh penerima lisensi dan lain sebagainya.

Menurut pasal 3 ayat 1 PP nNo. 16 Tahun 1997, bahwa pemberi waralaba sebelum mengadakan perjanjian dengan penerima waralaba wajib menyampaikan keteranganketerangan antara lain mengenai, nama pihak pemberi waralaba, hak atas kekayaan intelektual, persyaratan-persyaratan yang harus dipenuhi penerima waralaba, bantuan dan fasilitas yang ditawarkan, hak dan kewajiban, pengakhiran, pembatalan dan perpanjangan perjanjian waralaba.

\section{Bisnis Franchise dalam Perspektif Islam}

Dalam hukum Islam, kerja sama dalam hal jual beli dinamakan syirkah. Syirkah dibagi menjadi 3 bentuk yaitu :

1. Syirkah ibahah, yaitu : persekutuan hak semua orang untuk dibolehkan menikmati Vol. 20 No. 2 November 2018 
manfaat sesuatu yang belum ada di bawah kekuasaan seseorang.

2. Syirkah amlak (milik), yaitu : persekutuan antara dua orang atau lebih untuk memiliki suatu benda, syirkah amlak dibagi menjadi 2.

3. Syirkah akad, yaitu persekutuan antara dua orang atau lebih yang timbul dengan adanya perjanjian. Syirkah akad dibagi menjadi empat (4), yaitu :

- Syirkah amwal, yaitu persekutuan antara dua orang atau lebih dalam modal/harta.

- Syirkah a'mal, yaitu perjanjian persekutuan antara dua orang atau lebih untuk menerima pekerjaan dari pihak ketiga yang akan dikerjakan bersama dengan ketentuan upah dibagi menjadi dua.

- Syirkah wujuh, yaitu persekutuan antara dua orang atau lebih dengan modal harta dari pihak luar.

- Syirkah mudharabah, yaitu kemitraan (persekutuan) antara tenaga dan harta, seorang (supplier) memberikan hartanya kepada pihak lain (pengelola) yang digunakan untuk bisnis, dengan ketentuan bahwa keuntungan (laba) yang diperoleh akan dibagi menurut kesepakatan kedua belah pihak. Dasarnya bentuk mudharabah adalah peminjaman uang untuk keperluan bisnis.

Syirkah mudharabah ini dibagi menjadi 2 bentuk, yaitu mudharabah muthlaqah dalam hal ini pemodal memberikan hartanya kepada pelaksana untuk dimudharabahkan dengan tidak menentukan jenis kerja, tempat dan waktu serta orang.Sedangkan mudharabah muqayyadah (terikat suatu syarat), adalah pemilik modal menentukan salah satu dari jenis di atas.

Bila diperhatikan dari sudut bentuk perjanjian yang diadakan waralaba (franchising) dapat dikemukakan bahwa perjanjian itu sebenarnya merupakan pengembangan dari bentuk kerjasama (syirkah). Hal ini disebabkan karena dengan adanya perjanjian franchising, maka secara otomatis antara franchisor dan franchisee terbentuk hubungan kerja sama untuk waktu tertentu (sesuai dengan perjanjian). Kerja sama tersebut dimaksudkan untuk memperoleh keuntungan bagi kedua belah pihak. Dalam waralaba diterapkan prinsip keterbukaan dan kehati-hatian, hal ini sesuai dengan prinsip transaksi dalam Islam yaitu gharar (ketidakjelasan).

Bisnis waralaba ini pun mempunyai manfaat yang cukup berperan dalam meningkatkan pengembangan usaha kecil.Dari segi kemashlahatan usaha waralaba ini juga bernilai positif sehingga dapat dibenarkan menurut hukum Islam.

Untuk menciptakan sistem bisnis waralaba yang islami, diperlukan sistem nilaiSyariah sebagai filter moral bisnis yang bertujuan untuk menghindari berbagai penyimpangan moral bisnis (moral hazard). Filter tersebut adalah dengan komitmen menjauhi 7 (Tujuh) pantangan MAGHRIB, yaitu :

1) Masyir, yaitu segala bentuk spekulasi judi (Gambling) yang mematikan sector riil dan tidak produktif.

2) Asusila, yaitu praktik usaha yang melanggar kesusilaan dan norma social.

3) Gharar, yaitu segala transaksi yang tidak transparan dan tidak jelas, sehingga berpotensi merugikan salah satu pihak. 
4) Haram, yaitu obyek transaksi dan proyek usaha yang diharamkan syariah.

5) Riba, yaitu segala bentuk distorsi mata uang menjadi komoditas dengan mengenakan tambahan (bunga) pada transaksi kredit atau pinjaman.

6) Ihtiar, yaitu penimbunan dan monopoli barang dan jasa untuk tujuan permainan harga.

7) Berbahaya, yaitu segala bentuk transaksi dan usaha yang membahayakan individu maupun masyarakat serta bertentangan dengan kemaslahatan.

\section{Perbandingan Antara Hukum Positif dengan Hukum Islam mengenai Bisnis Franchise}

Setelah pemaparan yang panjang lebar mengenai franchising di atas, terdapat persamaan dan perbedaan franchising menurut hukum Islam dan hukum positif.

Persamaannya adalah Pertama, franchising adalah kerjasama (syirkah) yang saling menguntungkan, berarti franchising memang dapat dikatakan kategori dari syirkah dalam hukum Islam. Kedua, terdapat prestasi bagi penerima waralaba, hal ini sama dengan syirkah mudharabah muqayyadah. Ketiga, terdapat barang, jasa dan tenaga memenuhi salah satu syarat syirkah.Keempat, terdapat 2 orang atau lebih yang bertransaksi, sepakat, hal tertentu, ditulis (dicatat) dan oleh sebab tertentu sesuai dengan syarat akad, khususnya syirkah mudharabah.

Di atas telah dijelaskan bahwa franchising lebih hampir serupa dengan syirkah jenis mudharabah.Adapun perbedaannya terletak pada, Pertama, dalam syirkah mudharabah, modal harus berupa uang, tidak boleh barang.Sedangkan dalam franchising modal dapat dibantu oleh franchisor baik uang, barang atau tenaga professional. Kedua, dalam franchising terdapat kerja sama dalam bidang hak kekayaan intelektual (HAKI), yaitu merek dagang. Dan dalam hukum Islam hal tersebut termasuk syirkah amlak (hak milik).

Ketiga, tidak bolehnya kerja sama dalam hal berjualan barang haram, sedangkan dalam hukum positif tidak terdapat pembatasan terhadap hal tersebut, misal transaksi jualbeli barang najis dan memabukkan, seperti babi dan miras.

\section{PENUTUP}

Berdasarkan hasil pembahasan sebelumnya, maka dapat ditarik kesimpulan bahwa pada dasarnya Franchisee adalah sebuah perjanjian mengenai metode pendistribusian barang dan jasa kepada konsumen. Franchisor dalam jangka waktu tertentu memberikan lisensi kepada franchisee untuk melakukan usaha pendistribusian barang atau jasa di bawah nama identitas franchisor dalam wilayah tertentu. Usaha tersebut harus dijalankan sesuai dengan prosedur dan cara yang ditetapkan oleh franchisor. Franchisor memberikan bantuan (assistance) terhadap franchise, sebagai imbalannya franchisee membayar sejumlah uang berupa initial fee dan royalty. 
Kalau dalam hukum Islam, waralaba dengan model ini hampir serupa dengan model syirkah mudharabah (bagi hasil), tapi sudah mengalami perkembangan seiring berkembangnya zaman dan terdapat gabungan dengan jenis syirkah lainnya.Syirkah (persekutuan) dalam hukum Islam banyak sekali jenisnya dan terdapat perbedaan oleh para imam madzhab. Dan perlu diketahui bahwa dalam pola transaksi yang diatur oleh hukum Islam adalah menitikberatkan pada sisi moralitas yang lebih tinggi dari pada apapun

\section{DAFTAR PUSTAKA}

Budi Prasetyo, Perspektif Hukum Islam Terhadap Bisnis Waralaba (Franchise), Jurnal Vol 4 No. 2, 2007.

Departemen Pendidikan dan Kebudayaan RI, Kamus Besar Bahasa Indonesia, edisi ke III, Balai Pustaka Jakarta, tahun 2002

Gemala Dewi, Hukum Perikatan Islam di Indonesia, Badan Penerbit Fakultas Hukum UI, Jakarta, 2005, hal 194.

http://nindyadea.blogspot.co.id/2010/10/bisnisfranchisedalamperspektif-

hukum.htmlhttp://www.lawskripsi.com/index.php?option=com_content\&view=a $\underline{\text { rticle \&id }=214 \& \text { Itemid }=214}$

http://download.portalgaruda.org/article.php?article=58421\&val=4378. 